\title{
A PCR-Based Assay for Detection of Fusarium oxysporum f. sp. lactucae in Lettuce Seed
}

\author{
Gladys Chia Y. Mbofung and Barry M. Pryor, Division of Plant Pathology and Microbiology, Department of Plant
} Sciences, College of Agriculture and Life Sciences, University of Arizona, Tucson 85721

\begin{abstract}
Mbofung, G. C. Y., and Pryor, B. M. 2010. A PCR-based assay for detection of Fusarium oxysporum f. sp. lactucae in lettuce seed. Plant Dis. 94:860-866.

A nested polymerase chain reaction-based (nPCR) assay was developed and evaluated for the rapid detection of Fusarium oxysporum f. sp. lactucae in seed of lettuce. Three primers were designed from sequences of the intergenic spacer region of the rDNA and were used in the PCR amplifications. The first amplification employed the primer pair GYCF1 and GYCR4C and produced a product of 2,270 bp. The second amplification employed the forward primer GYCF1 and the nested primer R943 and produced a single 936-bp PCR product. The nPCR protocol developed successfully detected the target sequence in genomic DNA at $1 \mathrm{fg} / \mu \mathrm{l}$. A seed assay was tested that included a 4-day incubation step in which seed were maintained under high humidity conditions to increase fungal biomass for DNA extraction. In seed lots prepared by mixing known amounts of $F$. oxysporum f. sp. lactucae-infested seed with noninfested seed, this assay permitted the detection of the pathogen from lots with infestation rates as low as $0.1 \%$. Samples of lettuce seed obtained from 88 commercial lettuce seed lots were assayed for the pathogen by direct plating and by using the nPCR assay. The pathogen was not detected by either diagnostic method, suggesting the seed lots were pathogen free or the level was below detection limits.
\end{abstract}

Fusarium wilt of lettuce (Lactuca sativa) is a destructive disease that has recently become a serious concern for growers in several lettuce production areas of the world. The causal agent, Fusarium oxysporum Schlechtend.:Fr. f. sp. lactucae Matuo \& Motohashi, was first described in 1967 when it was responsible for significant losses in lettuce in Japan and pathogenicity on lettuce only was confirmed (23). In the United States, the disease was first reported in the San Joaquin valley of California in 1993, where it accounted for significant losses in lettuce yield in three fields near the town of Huron (16). In 2001, the disease was identified in five fields near the town of Yuma in Arizona (22). Fusarium wilt of lettuce has continued to spread in Arizona and, as of 2007, has been documented in more than 27 lettuce production fields. The disease has also continued its spread worldwide and has been reported in Taiwan (1996), Iran (1999), and Italy (2001) $(11,15,26)$.

The causal organism is a soilborne root and crown pathogen that causes severe stunting of lettuce plants, with diseased roots showing dark-brown streaking of the

Corresponding author: B. M. Pryor

E-mail: bmpryor@u.arizona.edu

Accepted for publication 16 March 2010.

doi:10.1094/PDIS-94-7-0860

(c) 2010 The American Phytopathological Society vascular tissue extending from the tap root into the stem (16). The occurrence of Fusarium wilt of lettuce in both Arizona and California is particularly serious due to the important position lettuce occupies in both agricultural economies. The means of dispersal of the pathogen between these two adjacent states and locally was hypothesized to be through the movement of infested farm equipment and mud-encrusted irrigation pipes used during the lettuce growing season (21). However, the occurrence of this disease in countries far from the original discovery area reveals the potential of the pathogen to spread long distances and suggests the possibility of seedborne dispersal.

Only two vegetative compatibility groups have been described within the three known races of $F$. oxysporum $\mathrm{f}$. sp. lactucae, to which standard nomenclature was ascribed $(7,8,15,30,36)$. All race 1 isolates were assigned to the vegetative compatible group 0300 (29). To date, only race 1 has been reported outside of Japan $(9,25)$. The spread of this specific race to several distant and disjunct countries in a relatively short period of time suggests movement via infested seed, although this has not been conclusively documented. However, this is consistent with the mode of dispersal of many other Fusarium spp. such as $F$. oxysporum f. sp. largenariae, $F$. oxysporum f. sp. vasinfectum, $F$. oxysporum f. sp. erythroxyli, and $F$. moniliforme $(3,10,19,37)$. In addition, the movement of Fusarium spp. through the vascular system of the pedicel and into the seed embryo has been documented for other formae speciales such as matthioli, largenariae, vasinfectum, and pisi, revealing that, in some cases, Fusarium spp. can infect as well as infest seed $(2,19,33,35)$. In 2004, F. oxysporum f. sp. lactucae was recovered by direct plating of samples from several lots of lettuce seed used to plant fields in Italy in which Fusarium wilt was subsequently detected at incidences of 20 to $60 \%$ (12). Although the rate of recovery of the pathogen in positive seed lots was low, these data confirmed the potential for seedborne spread of this pathogen.

Accurate testing for seedborne pathogens is an important disease management tool for reducing the spread of disease into new regions and making accurate decisions regarding the appropriate use of seed treatment, and for seed certification programs. Conventional methods for seed health testing include the freezer blotter technique or plating on selective media $(17,28)$, followed by identification of pathogens via microscopy. These methods are slow and labor intensive, require skilled personnel, and are not suited for the rapid and high-throughput type of testing that is desired for screening commercial seed (39). In addition, the low level of sensitivity and specificity limits the use of these methods because other fungal pathogens with similar morphology may also grow on the selective media.

Diagnostic methods based on polymerase chain reaction (PCR) have high analytical sensitivity to discriminate between different strains of fungi and have been used to detect a number of form species within the $F$. oxysporum complex such as formae speciales phaseoli, lycopersici, radicis-lycopersici, basilici, niveum, and canariensis $(1,5,13,20,31,40)$. In addition to high sensitivity and specificity, PCR-based methods have the advantage in that a large number of samples can be processed within a short period of time and can be conveniently applied to commercial seed testing and certification. However, the use of PCR-based detection methods in seed assays is challenged by the high levels of polysaccharides frequently present in seed which significantly affect the efficiency of DNA extraction, and the presence of PCR inhibitors that can negatively impact successful amplification of the recovered DNA $(6,14,27)$. 
The objectives of this study were to optimize methods for extracting fungal DNA directly from lettuce seed, design PCR primers specific to $F$. oxysporum f. sp. lactucae, and develop a sensitive and specific PCR-based method for the detection of the seedborne pathogen. In addition, lots of commercial lettuce seed were assayed by both cultural and PCR-based methods in order to develop preliminary data as to the presence of the pathogen in lettuce seed used in Arizona.

\section{MATERIALS AND METHODS}

Fungal isolates. Test isolates of $F$. $o x$ ysporum $\mathrm{f}$. sp. lactucae used in this study were recovered from diseased lettuce roots and soil collected in Arizona. Cultures were grown on potato dextrose agar (PDA; Difco Laboratories, Plymouth, MN) at $23^{\circ} \mathrm{C}$ and stored on silica gel at $4^{\circ} \mathrm{C}$. Each isolate was identified based on standard morphological criteria, comparisons with type or representative isolates, pathogenicity tests, and published descriptions (16). These and other fungal isolates used and their sources are listed in Table 1.

DNA isolation. Liquid cultures of all isolates were prepared by flooding agar plates (PDA) containing 5-day-old cultures of test fungi with $10 \mathrm{ml}$ of sterile $\mathrm{H}_{2} \mathrm{O}$ and dislodging mycelia and conidia with a pipette tip. A suspension $(2 \mathrm{ml})$ was added to $100 \mathrm{ml}$ of sterile liquid growth medium (20 g of D-glucose, $1.2 \mathrm{~g}$ of DL-asparagine, $1.2 \mathrm{~g}$ of $\mathrm{K}_{2} \mathrm{HPO}_{4}, 0.5 \mathrm{~g}$ of yeast extract, 0.5 $\mathrm{g}$ of $\mathrm{MgSO}_{4} \cdot 7 \mathrm{H}_{2} \mathrm{O}$, and $0.1 \mathrm{~g}$ of $\mathrm{NaCl}$ per liter) in a 250-ml Erlenmeyer flask. The flasks were incubated on a rotary shaker at $120 \mathrm{rpm}$ for 5 days at $22^{\circ} \mathrm{C}$. Mycelia were harvested by filtration through Miracloth (Calbiochem, EMD Biosciences Inc., San Diego, CA), lyophilized, and stored under desiccation at $4{ }^{\circ} \mathrm{C}$. Extraction of fungal total genomic DNA was accomplished using the BIO 101 Fast DNA kit (Qbiogene, Irvine, CA) according to the manufacturer's protocols.

Design of $F$. oxysporum f. sp. lactucaespecific primer sets and $\mathrm{nPCR}$ protocol. Full-length intergenic spacer (IGS) rDNA sequences generated in a previous study (24) were used to design two primer sets for use in a nested-PCR detection protocol. Primers were designed with the program Primer 3 (Steve Rozen and Helen J. Skaletsky, Totowa, NJ) and evaluated using the program Amplify (version 3.1; University of Wisconsin, Madison). Criteria for sequence specificity were such that the outer primers would amplify Fusarium spp. and the inner primer was to amplify more specific taxa within $F$. oxysporum. In all experiments, the first PCR was carried out in a volume of $50 \mu \mathrm{l}$ containing $2 \mu \mathrm{l}$ of total genomic DNA, $0.06 \mathrm{mM}$ each primer, $2 \mathrm{mM}$ each dNTP, $2 \mathrm{mM} \mathrm{MgCl}_{2}$, and 0.03 $\mathrm{U}$ of Biolase Taq polymerase (Bioline USA Inc., Randolph, MA). The second PCR assay was also carried out in a vol- ume of $50 \mu \mathrm{l}$ containing the same reagent concentrations, except the first PCR products were diluted at $1 \mu \mathrm{l}$ of product to $25 \mu \mathrm{l}$ of Tris-EDTA (TE) buffer and $1 \mu \mathrm{l}$ of the diluted product used in the PCR. PCR reactions were carried out in a PTC-100 thermal cycler programmed for the following parameters: for the initial PCR, the parameters were $94^{\circ} \mathrm{C}$ for $1 \mathrm{~min}$ and 25 cycles at $94^{\circ} \mathrm{C}$ for $30 \mathrm{~s}, 65^{\circ} \mathrm{C}$ for $2 \min 24$ $\mathrm{s}$, and $72^{\circ} \mathrm{C}$ for $1 \mathrm{~min}$. For the nested PCR (nPCR), the parameters were $94^{\circ} \mathrm{C}$ for 1 min; 25 cycles at $94^{\circ} \mathrm{C}$ for $30 \mathrm{~s}, 63^{\circ} \mathrm{C}$ for $30 \mathrm{~s}$, and $72^{\circ} \mathrm{C}$ for $1 \mathrm{~min}$; and a final extension period of $10 \mathrm{~min}$ at $72^{\circ} \mathrm{C}$. PCRamplified DNA fragments were fractionated in $1 \%$ agarose gels in $0.5 \times$ Trisborate-EDTA buffer and visualized in ethidium bromide.

Sensitivity and specificity of $F$. oxysporum f. sp. lactucae primer sets. To determine the sensitivity of the primers, 10 -fold serial dilutions of $F$. oxysporum $\mathrm{f}$. sp. lactucae total genomic DNA were prepared in TE buffer (concentrations ranged from $10 \mathrm{ng} / \mu \mathrm{l}$ to $1 \mathrm{fg} / \mu \mathrm{l})$, and the ability of the primers to direct the amplification of the target DNA fragment from decreasing concentrations of DNA was determined. To determine specificity, the primer pairs were tested on total genomic DNA (10 $\mathrm{ng} / \mu \mathrm{l})$ from four isolates of $F$. oxysporum f. sp. lactucae, 24 isolates of different formae speciales of $F$. oxysporum, six nonoxysporum Fusarium spp., and five other fungi commonly associated with lettuce seed in California and Arizona (Table 1). All PCR assays were carried out as per the protocol described above. In both tests, the nPCR primer combination was run to compare sensitivity and specificity in detection.

Seed assay protocol. The ability of the nPCR protocol to detect $F$. oxysporum f. sp. lactucae in lettuce seed was examined in a modification of a PCR-based seed assay protocol developed in an earlier study (32). For each seed assay, $1 \mathrm{~g}$ of lettuce seed (approximately 1,200 to 1,300 seeds) per seed lot was evenly distributed over the bottom of a $15-\mathrm{mm}$ plastic petri dish. The dish was placed on a rigid mesh support in a plastic container ( 31 by 22 by $10 \mathrm{~cm}$ ) and water was added beneath the mesh support to a depth of $1.5 \mathrm{~cm}$. A fine mist of sterile water was initially applied to the seed in the dish with a spray bottle (approximate duration of misting was 1 to $2 \mathrm{~s})$. After misting, the petri dish cover was placed slightly ajar and the top was re-

Table 1. Sources and species of fungi used in this study

\begin{tabular}{|c|c|c|}
\hline Species & Isolate & Source $^{a}$ \\
\hline Fusarium oxysporum f. sp. lactucae & HL2 & T. R. Gordon \\
\hline F. oxysporum f. sp. lactucae & FOL. 10 & T. R. Gordon \\
\hline F. oxysporum f. sp. lactucae & 2002-06 & B. M. Pryor \\
\hline F. oxysporum f. sp. lactucae & BMP1382 & B. M. Pryor \\
\hline F. oxysporum f. sp.fabae & NRRL 26411 & K. O'Donnell \\
\hline F. oxysporum f. sp. batatas & NRRL 22535 & K. O'Donnell \\
\hline F. oxysporum f. sp. callistephi & NRRL 22536 & K. O'Donnell \\
\hline F. oxysporum f. sp. heliotropa & NRRL 26412 & K. O’Donnell \\
\hline F. oxysporum f. sp. rhois & NRRL 26227 & K. O'Donnell \\
\hline F. oxysporum f. sp. сераe & NRRL 22538 & K. O'Donnell \\
\hline F. oxysporum f. sp. opuntiarum & NRRL28934 & K. O’Donnell \\
\hline F. oxysporum f. sp. phaseoli & NRRL 26445 & K. O'Donnell \\
\hline F. oxysporum f. sp. vasinfectum & NRRL 25231 & K. O'Donnell \\
\hline F. oxysporum f. sp. medicaginis & NRRL 22546 & K. O'Donnell \\
\hline F. oxysporum f. sp. matthiolae & NRRL 22545 & K. O'Donnell \\
\hline F. oxysporum f. sp. spinaciae & NRRL 26871 & K. O’Donnell \\
\hline F. oxysporum f. sp. tulipae & NRRL 26954 & K. O'Donnell \\
\hline F. oxysporum f. sp. chrysanthemi & NRRL 22539 & K. O'Donnell \\
\hline F. oxysporum f. sp. albedinis & NRRL 26622 & K. O'Donnell \\
\hline F. oxysporum f. sp. asparagi & FOA50 & E. Nigh \\
\hline F. oxysporum f. sp. melonis & TX388 & T. R. Gordon \\
\hline F. oxysporum f. sp. lycopersici & FOLR2 & T. R. Gordon \\
\hline F. oxysporum isolate 1 (from soil) & BMP 1388 & B. M. Pryor \\
\hline F. oxysporum isolate 2 (from soil) & BMP1397 & B. M. Pryor \\
\hline F. subglutinans & BMP1462 & B. M. Pryor \\
\hline F. proliferatum & 31.X4 & E. Nigh \\
\hline F. graminearum & BMP1461 & B. M. Pryor \\
\hline F. acuminatum & BMP1460 & B. M. Pryor \\
\hline F. concolor & BMP1454 & B. M. Pryor \\
\hline F. culmorum & BMP1453 & B. M. Pryor \\
\hline Bipolaris tetramera & BMP0382 & B. M. Pryor \\
\hline Exserohilum pedicellatum & BMP0384 & B. M. Pryor \\
\hline Alternaria alternata isolate 1 & BMP0196 & B. M. Pryor \\
\hline A. alternata isolate 2 & BMP0208 & B. M. Pryor \\
\hline A. alternata isolate 3 & BMP0255 & B. M. Pryor \\
\hline
\end{tabular}

${ }^{a}$ Sources of fungal isolates: T. R. Gordon, University of California, Davis, 95616; B. M. Pryor, Department of Plant Sciences, University of Arizona, Tucson 85721; Kerry O'Donnell, National Center for Agricultural Utilization Research, Peoria, IL; Edward Nigh, Department of Plant Sciences, University of Arizona, Tucson. 
placed over the plastic container to maintain conditions of high humidity that would promote growth of fungi from test seed. The set-up was incubated in the dark for 4 days at $28^{\circ} \mathrm{C}$.

After incubation, $5 \mathrm{ml}$ of lysis buffer (1\% sodium dodecyl sulfate; $10 \mathrm{mM}$ Tris $\mathrm{HCl}, \mathrm{pH} 8.0 ; 10 \mathrm{mM}$ EDTA, $\mathrm{pH} 8.0$; and $0.5 \mathrm{M} \mathrm{NaCl}$ ) was added to the dish and the dish was rocked to fully moisten all seed and fungal hyphae growing on the seed. The dish was then incubated on a rotary shaker at $60 \mathrm{rpm}$ for $15 \mathrm{~min}$ at $23^{\circ} \mathrm{C}$. The contents of the dish (seed, mycelia, and lysis buffer) were transferred into a $15-\mathrm{ml}$ centrifuge tube and $3 \mathrm{ml}$ of phenolchloroform (1:1, vol/vol) was added. The tube was vigorously shaken for $1 \mathrm{~min}$ and centrifuged at $9,000 \times g$ for $20 \mathrm{~min}$ at $4^{\circ} \mathrm{C}$. The aqueous phase was transferred into a tion performed with $3 \mathrm{ml}$ of chloroform. Approximately $3 \mathrm{ml}$ of aqueous phase was recovered, and $500 \mu \mathrm{l}$ of $10 \%$ polyvinylpolypyrrolidone was added. The tube was gently rocked on a rotary shaker for $5 \mathrm{~min}$ and then centrifuged at $9,000 \times g$ for 10 min at $4{ }^{\circ} \mathrm{C}$. Supernatant $(2 \mathrm{ml})$ was transferred to a new tube and $0.9 \mathrm{ml}$ of Bio101 binding matrix was added. The solution was incubated for $20 \mathrm{~min}$ at $23^{\circ} \mathrm{C}$ with periodic agitation, and then centrifuged at $12,000 \times g$ for $1 \mathrm{~min}$. The matrix pellet was washed two times with $0.5 \mathrm{ml}$ of $70 \%$ EtOH and then dried at $37^{\circ} \mathrm{C}$ overnight. DNA was eluted from the dried matrix by adding $100 \mu \mathrm{l}$ of TE buffer and incubating for $10 \mathrm{~min}$ at $55^{\circ} \mathrm{C}$. After incubation, matrix and buffer were transferred to a $1.5-\mathrm{ml}$ microfuge tube and centrifuged at 12,000 $\times g$ for $1 \mathrm{~min}$, and the TE buffer solution containing DNA was recovered. ried out as previously described for total genomic DNA, except that (i) $2 \mu$ of DNA extract was used and (ii) $2.5 \mu \mathrm{l}$ of dimethyl sulfoxide (DMSO; Sigma-Aldrich Inc., St. Louis, MO) was added to the PCR reaction mixture to a final concentration of $5 \%$. To determine whether the DMSO altered primer performance, the primer sets were tested for sensitivity and specificity with or without 5\% DMSO. To determine the limit of detection of PCR-based seed assay, samples of noninfested seed were mixed (wt/wt) with artificially infested seed new centrifuge tube and a second extrac-

PCR with the recovered DNA was car-

(100\% infestation level) to generate lots of $5 \mathrm{~g}$ each with $100,10,5,1,0.5,0.2$, and $0.1 \%$ levels of contamination. Each seed lot was assayed in duplicate and the experiment was conducted twice.

Assay of commercial seed lots. Samples of lettuce seed ( $n=88,500$ to $1,500 \mathrm{~g}$ in each sample) obtained from commercial seed lots were assayed for the presence of $F$. oxysporum f. sp. lactucae by both the agar plate method and nPCR-based assay. The samples were provided by various commercial seed producers in Arizona and California and were representative of lots used for planting production fields in Arizona. For the agar plate method, isolations were carried out on subsamples of nondisinfested seed (720 to 1,200 seeds per lot). Twelve agar plates (Komada's medium) per lot were incubated for 4 days under cool-white fluorescent light (12 h of light and $12 \mathrm{~h}$ of darkness) at $25^{\circ} \mathrm{C}$. Putative $F$. oxysporum colonies were subcultured on three media (Komada's, PDA, and carnation leaf agar containing $0.5 \% \mathrm{KCl}$ ) and their identity was confirmed by morphological characterization (4). For the PCRbased assay, DNA extraction was performed as described previously and each seed lot was assayed four times.

Pathogenicity of $\boldsymbol{F}$. oxysporum isolates recovered from lettuce seed. Cultures of putative $F$. oxysporum isolates obtained from assayed seed were grown on PDA for 10 days under $12 \mathrm{~h}$ of fluorescent light. Each plate was then flooded with $20 \mathrm{ml}$ of $0.5 \% \mathrm{KCl}$ and the spores were dislodged using a rubber spatula to generate a spore suspension. The spore suspensions were filtered through four layers of cheese cloth to remove fungal hyphae and the spore concentration was adjusted to $10^{6}$ spores $/ \mathrm{ml}$. All recovered isolates were tested for pathogenicity on the commercial lettuce cv. Winterhaven. Roots of 10-dayold seedlings were washed in running tap water, and approximately $1 \mathrm{~cm}$ of root tip was removed. The wounded roots were dipped in a spore suspension for $10 \mathrm{~min}$. For each fungal isolate, eight inoculated seedlings were transplanted to 20 -cm-wide plastic pots containing a sterile mix of 1 part peat, 1 part vermiculite, and 2 parts sand. The experiment was set up in the greenhouse $\left(24\right.$ to $29^{\circ} \mathrm{C}$, relative humidity $=50$ to $60 \%$ ) in a completely randomized

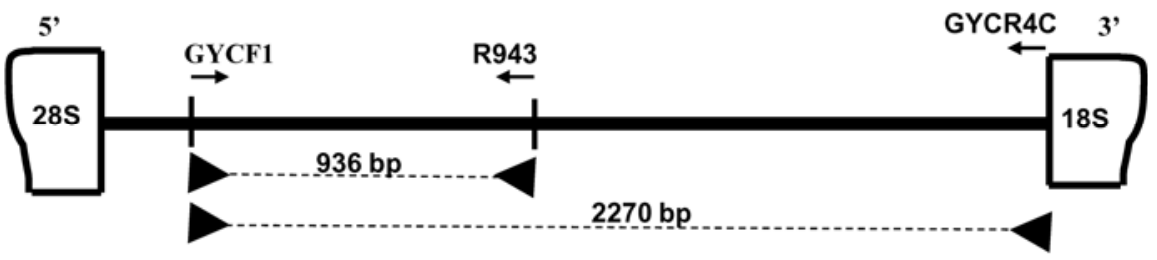

Fig. 1. Representation of the intergenic spacer (IGS) ribosomal DNA region showing primary and nested primers. Primer GYF1 primes at position $212 \mathrm{bp}$ on the IGS. Specificity of the nested primer was attained by designing primer R943 at a polymorphic site unique to the forma speciales lactucae isolates. design. Negative control plants were prepared similarly but the wounded roots were dipped in $0.5 \% \mathrm{KCl}$. Plants inoculated with the $F$. oxysporum f. sp. lactucae reference isolate HL1 constituted the positive control. Plants were examined for wilt symptoms 7 days after inoculation and were scored for disease 20 days after inoculation.

\section{RESULTS}

Design of $F$. oxysporum f. sp. lactucae primer sets. Part of the nucleotide sequences of $28 \mathrm{~S}$ and $18 \mathrm{~S}$ rDNA, including the $5^{\prime}$ and $3^{\prime}$ end of the IGS with polymorphisms unique to the $F$. oxysporum $\mathrm{f}$. sp. lactucae isolates, were determined and, from these sequences, the first PCR primer pair was designed (Fig. 1). The forward primer sequence was GYCF1 (5'CTCCGGATTTCTGGAGACTTG- ${ }^{\prime}$ ) and the reverse primer sequence was GYCR4C (5'-ACTATCGTGTGCCGGGGTTGGC-3'). The nested right primer, R943 (5'CCCATACTATATACCAGACG-3'), was designed based upon a single base pair polymorphism at position 1,147 within the IGS region that is unique to lactucae isolates (Fig. 1) (25).

Sensitivity and specificity of the $F$. oxysporum f. sp. lactucae primer sets. In specificity tests with total genomic DNA from 13 other fungal species, the first primer pair directed amplification of a product of approximately 2,270 bp from total genomic DNA from the lactucae isolates, two nonpathogenic $F$. oxysporum isolates, and F. subglutinans (Fig. 2A). No target DNA fragments were amplified from total genomic DNA of the other fungal species. The second primer pair directed the amplification of a single 936-bp target fragment from the primary PCR product only from the lactucae isolates. No DNA fragments were amplified from any of the other 13 fungal isolates (Fig. 2B). The first primer pair amplified the target fragment from 14 of the other 15 formae speciales (Fig. 3A). In a previous reaction, the target was not amplified from the formae speciales tulipae, chrysanthemi, and albedinis (results not shown). In the second PCR, the target fragment was amplified from only 8 of the 14 formae speciales (lycopersici, asparagi, callistephi, batatas, cepae, vasinfectum race 7 , rhois, and matthiolae). The primers also amplified a slightly larger fragment from the formae speciales heliotropa and phaseoli (Fig. 3A and B). In sensitivity tests with serial dilutions of $F$. oxysporum f. sp. lactucae total genomic DNA, the limit of detection (i.e., the lowest concentration of total genomic DNA from which the fragment was amplified) for the outer primer set was $200 \mathrm{pg}$ and that for the nested primer pair was $2 \mathrm{fg}$ (Fig. 4A and B).

Seed assay protocol. In experiments to determine the limit of detection (sensitivity) of the $F$. oxysporum f. sp. lactucae- 
specific primers in a seed assay, the target DNA sequence was detected from duplicate samples of undiluted DNA extracts from seed lots at infestation levels of $10 \%$ in the first PCR. The subsequent nPCR detected the target fragment in samples at infestation levels as low as $0.5 \%$ (results not shown). In the repeated experiment, the first primer set directed the amplification of the target sequence from undiluted extracts with infestation levels as low as $5 \%$ (Fig 5A). The nested primer amplified the target sequence from seed lots with infestation levels as low as $0.1 \%$ (Fig. 5B). No DNA fragments were amplified from equivalent extracts prepared from noninfested seed lots.

Assay of commercial seed lots. A direct plating assay revealed that several of the commercial seed lots were infested with other saprobic fungi, including Alternaria spp., Penicillium spp., and Aspergillus spp. In only three seed lots were $F$. oxysporum colonies isolated, and nine putative $F$. oxysporum f. sp. lactucae isolates were selected for further testing. In pathogenicity tests, none of the isolates obtained were pathogenic (results not shown). In addition, no target sequence was amplified from any of the commercial seed lots using the nPCR-based seed assay (results not shown).

\section{DISCUSSION}

The PCR-based assay developed for detection of $F$. oxysporum f. sp. lactucae on lettuce seed represents a combination of techniques aimed at optimizing extraction and amplification protocols which would allow for reliable detection of the fungus from infested seed. This assay proved to be sensitive enough for the detection of $F$. oxysporum f. sp. lactucae on infested lettuce seed. PCR-based seed assays for detecting fungal pathogens are often challenging due to low pathogen populations frequently associated with infested seed as well as the presence of PCR inhibitors commonly present in seed tissues $(30,37)$. Hence, assays must optimize both quantity and quality of target DNA during the extraction process. In this assay, a preincubation step was used to increase fungal biomass on seed prior to DNA extraction in order to increase the low levels of target $F$. oxysporum f. sp. lactucae normally found on lettuce seed and, subsequently, the opportunity for successful DNA recovery. This step has also been successfully used in other assays designed for the detection of fungi in seed when low fungal biomass was problematic $(32,38)$.

Other methods that have proven successful for increasing fungal biomass in previous studies include incubating seed in liquid culture and on moistened filter paper (32). Even though these methods increased the biomass of the fungal pathogen on seed, when used in this seed assay, the PCR amplification of the target $F$. oxy-
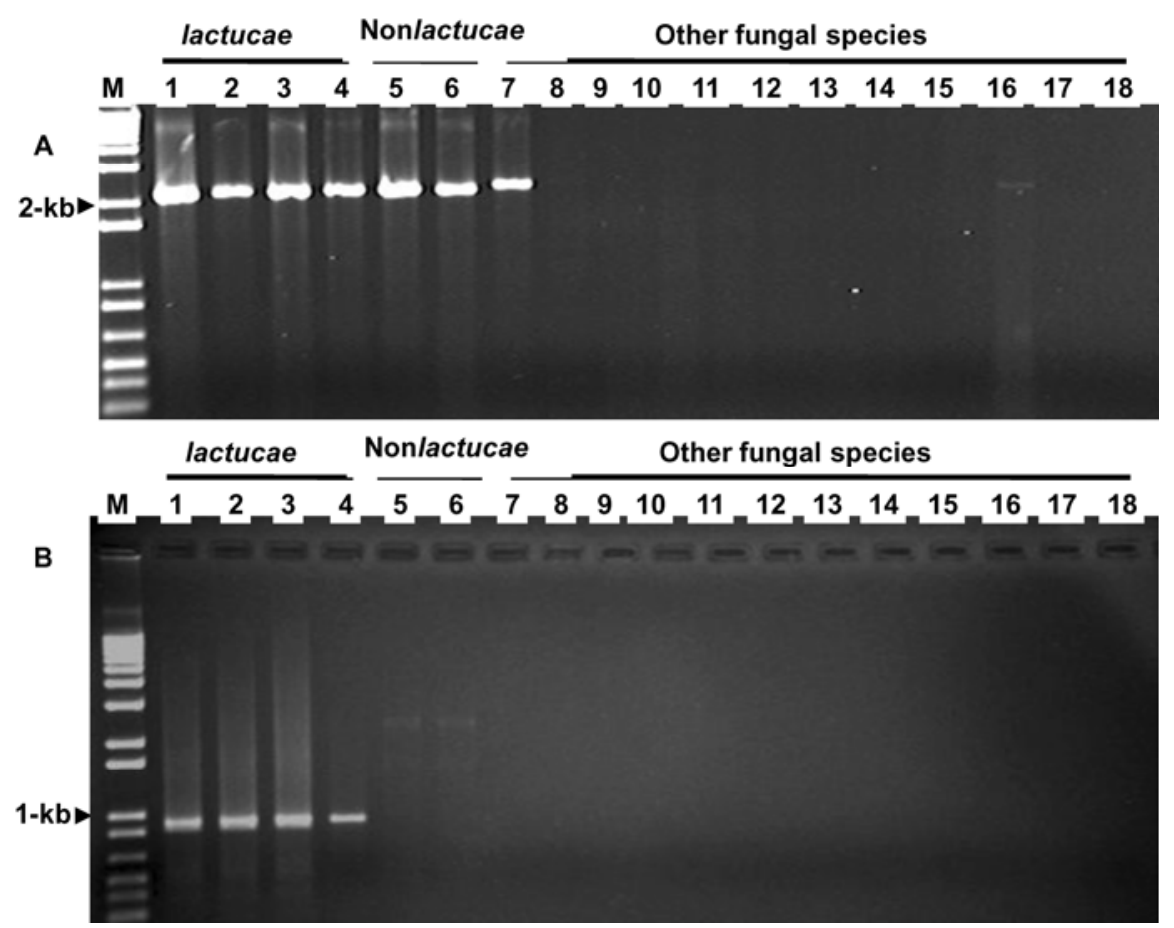

Fig. 2. A, Specificity of the primer pair GYCF1 and GYCR4C. The primers were used in the polymerase chain reaction with total genomic DNA (20 ng) of various fungal species. The primers crossamplified a fragment of the same size as the target sequence from two nonpathogenic Fusarium oxysporum isolate, BMP 1388 and BMP 1397 (lanes 5 and 6), and F. subglutinans (lane 7). B, Improved specificity with primer pair GYCF1 and R943. Lanes 1-4: F. oxysporum f. sp. lactucae. Lanes 5-18: $F$. oxysporum, $F$. oxysporum, $F$. subglutinans, $F$. proliferatum, $F$. graminearum, $F$. acuminatum, $F$. concolor, $F$. culmorum, Bipolaris tetramera, Exoserohilium pedicillatum, Alternaria alternata isolate 1, A. alternata isolate 2, A. alternata isolate 3, and negative control, respectively. Lane $\mathrm{M}$ contains the 1-kb-plus DNA ladder.
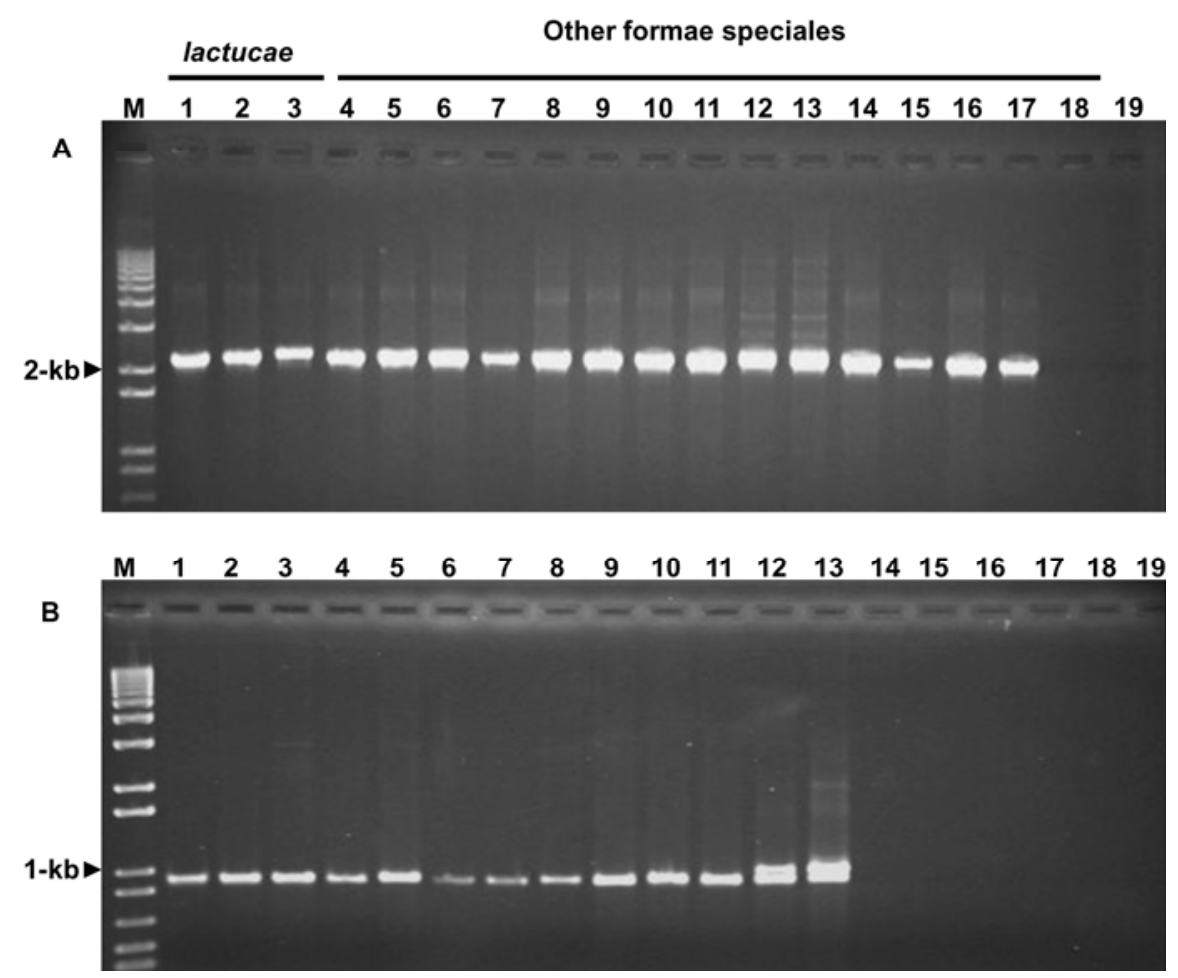

Fig. 3. A, Specificity of the primer pair GYCF1 and GYCR4C used in the polymerase chain reaction with total genomic DNA (20 ng) of 15 formae speciales of Fusarium oxysporum. Lanes 1-3: F. oxysporum f. sp. lactucae. Lane 4-18: formae speciales lycopersici, asparagi, callistephi, batatas, cepae, vasinfectum, rhois, matthiolae, phaseoli, heliotropa, melonis, spinaciae, medicaginis, opuntiarum, and fabae, respectively. B, Improved specificity of the primer pair GYCF1/R943. Lanes M and 19 contains the 1-kb-plus DNA ladder and the negative control, respectively. 

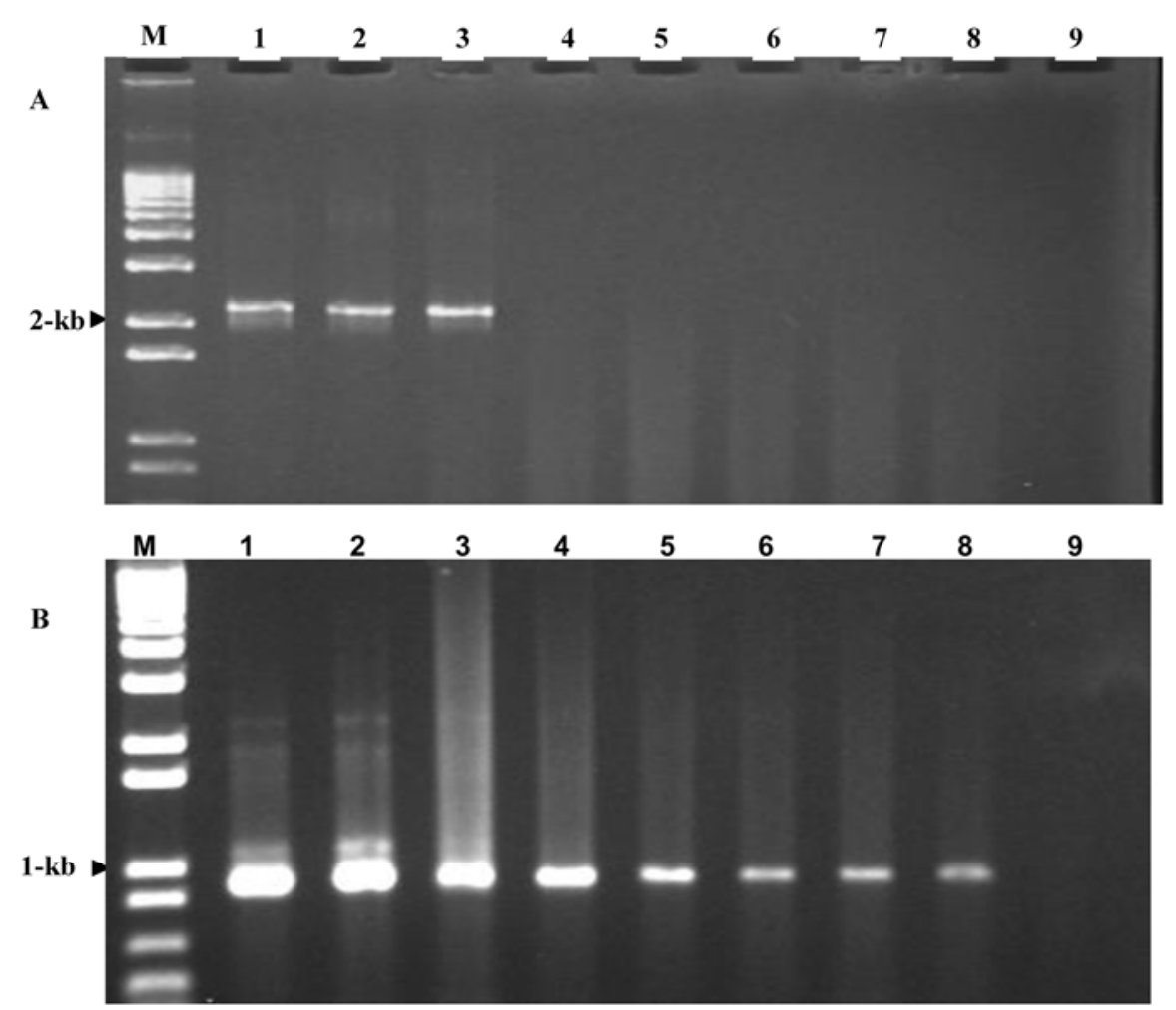

Fig. 4. A, Limit of detection of primer pair GYCF1 and GYCR4C. The first polymerase chain reaction (PCR) was performed with serial dilutions of Fusarium oxysporum f. sp. lactucae total genomic DNA. Lanes 1-9: $20 \mathrm{ng}, 2 \mathrm{ng}, 200 \mathrm{pg}, 20 \mathrm{pg}, 2 \mathrm{pg}, 200 \mathrm{fg}, 20 \mathrm{fg}$, and $2 \mathrm{fg}$ of total genomic DNA and no DNA, respectively. Lane $M$ contains the 1-kb-plus DNA marker. B, Improved sensitivity of primer pair GYCF1 and R943. The second PCR was performed with a 2:50 diluted product of the first PCR.
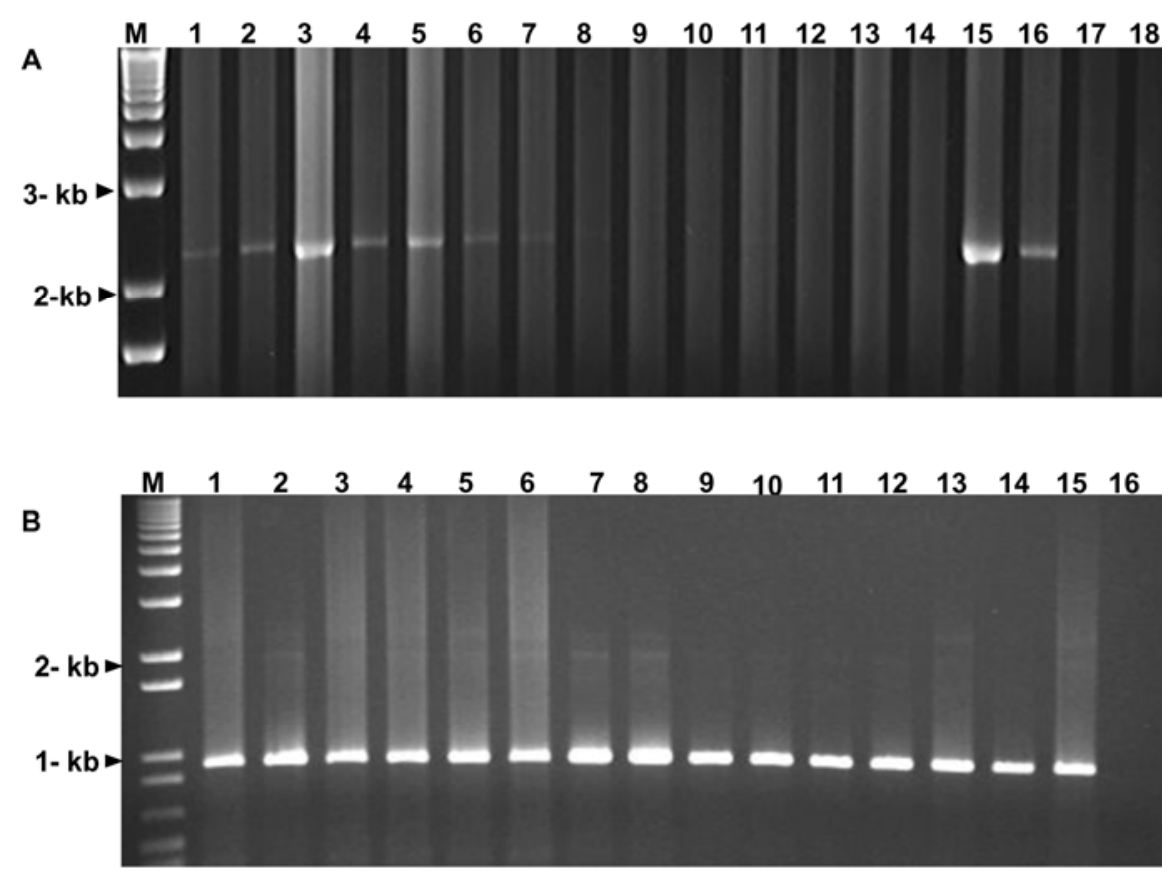

Fig. 5. A, Limit of detection of Fusarium oxysporum f. sp. lactucae with the primer pair GYCF1/GYCR4C in lettuce seed at different levels of artificial infestation. Lanes 1-16 show results from two independent DNA extractions for each seed lot having the indicated rates of infestation: Lanes 1 and 2,100\%; lanes 3 and 4,10\%; lanes 5 and 6, 5\%; lanes 7 and $8,1 \%$; lanes 9 and $10,0.5 \%$; lanes 11 and 12, 0.2\%; lanes 13 and 14, 0.1\%; lanes 15 and 16, two positive controls, lanes 17 and 18, no-template controls. B, Improved sensitivity with primers GYCF1/R943 showing the limit of detection in infested seed at $0.1 \%$. Lanes 1 and 2, 100\%; lanes 3 and 4, 10\%; lanes 5 and 6, 5\%; lanes 7 and 8, 1\%; lanes 9 and 10, 0.5\%; lanes 11 and 12, 0.2\%; lanes 13 and 14, 0.1\%. Lane 15, positive control; and lane 16, negative control, were not loaded in duplicates as above. sporum f. sp. lactucae DNA from total DNA extracted from lettuce seed was inconsistent even for seed that contained high levels of the pathogen infested artificially (data not shown). These inconsistencies were attributed to the presence of PCR inhibitors released from the seed and, in some cases, the suppression of growth of the target fungus by fast-growing bacteria. Furthermore, $1 \mathrm{~g}$ of lettuce seed (which is approximately 1,200 to 1,300 seeds) was assayed in a single 100-by-15-mm petri dish in this study. Larger seed samples could be assayed by either increasing the number of petri dishes or by using largersized petri dishes.

PCR inhibitors associated with vegetable seed can constitute obstacles in the development of assays of this kind $(6,18)$. In this study, when the seed were ground for DNA extraction, amplification of the target sequence was inconsistent due to PCR inhibitors released from the lettuce seed. In addition, PCR inhibitors were consistently encountered in DNA extracts from ground lettuce seed, regardless of whether they were spiked with genomic DNA from $F$. oxysporum f. sp. lactucae or other fungal species (data not shown). Thus, it was necessary to develop a method for recovery of fungal DNA from seed while minimizing the release of inhibitors from the seed. The extraction method used in this study allowed for the recovery of a sufficient amount of fungal DNA with a minimal amount of PCR inhibitors released from the seed. Even though seed were not ground, the DNA recovered after phenol-chloroform extraction and ethanol precipitation often contained brown pigments (e.g., phenolics) that could not be removed by washing with ethanol or repeated precipitation (data not shown). To reduce these contaminants, silica matrix (Qbiogene, Irvine, CA) purification was used instead of ethanol precipitation to recover the DNA from seed extracts. In subsequent reactions, the DNA recovered with this matrix did not contain brown pigments and the target DNA sequence was consistently amplified from seed DNA extracts, without the requirement of further dilution or addition of DMSO.

The nPCR was 10-fold more sensitive than the primer combination GYCF1/ GYCR4C for detection from total genomic DNA in artificially infested lettuce seed. This level of sensitivity implies that the second primer combination could be used for rapidly screening seed for infestation. Nevertheless, when greater sensitivity is required, then the nPCR technique should be used. The outer primer set was not species specific because it also directed the amplification of an approximately 2,270bp DNA fragment from two nonpathogenic F. oxysporum isolates and from $F$. subglutinans. However, this would not result in false positives in lettuce seed assays be- 
cause these isolates did not possess the polymorphic site that formed the basis of the improved selectivity of the $3^{\prime}$ nested primers. Thus, this initial cross-reaction was eliminated in the subsequent PCR with the nested primer, which greatly improved both the sensitivity and specificity of the assay. The cross-reactivity among select $F$. oxysporum formae speciales would also not be problematic because these strains would not be associated with lettuce seed and their presence would not be expected. However, if additional confirmation of positive results is necessary, the pathogenicity tests described would effectively resolve this question. Moreover, the protocol for isolation of fungal DNA from seed developed for this PCR-based detection assay is flexible enough that new primers can easily be incorporated into modified assays, thereby providing a means for continually updating and improving the specificity and sensitivity of detection. Given the intensity of the bands obtained with the $0.1 \%$ seed infestation in the nPCR, it is possible that infestation levels lower than $0.1 \%$ could be detected with these primers. However, we did not assay seed below this infestation level in our tests.

The negative results obtained from the PCR assay on 88 commercial seed lots supports the hypothesis that the introduction and rapid spread of Fusarium wilt of lettuce in Arizona may have been due to contaminated farm equipment moving from California into Arizona and between fields in Arizona (21). However, the original lots of lettuce seed from 2001 used to seed the fields in which the disease was first reported in Arizona were not included in the samples assayed. Therefore, it is not known if these original seed lots were infested and were the source of the majority of the current infestation in Arizona. In addition, the samples for testing were supplied by commercial growers and seed producers and may not have been statistically robust representatives of the original seed lots. Thus, the negative results obtained from the commercial seed assays may not be a true representation of the infestation level of these lots. However, most of the commercial seed lots that were tested were produced in the Huron area of California where Fusarium wilt of lettuce was first reported in the United States and where $80 \%$ of all lettuce seed used in Arizona is produced (Ron Berens, Arizona Seed Trade Association, personal communication). Considering that Fusarium wilt is still reported in this area, there is a risk of lettuce seed becoming contaminated with the pathogen.

In Italy, it was established that the spread of the disease was due to the use of contaminated seed as propagation material (12). The PCR-based assay developed for the detection of $F$. oxysporum f. sp. lactucae on infested lettuce seed in this study is accurate, sensitive, and reliable, and could easily incorporate other primers for $F$. oxysporum f. sp. lactucae that are specific for other races. Recently, Shimazu et al. (34) developed two sequence-tagged sites using randomly amplified polymorphic DNA markers for the identification of the three races of $F$. oxysporum $\mathrm{f}$. sp. lactucae; however, the authors did not incorporate these primers into a comprehensive seed assay protocol. These sequence-tagged sites could be incorporated into the seed assay presented in this work to identify all races of $F$. oxysporum $\mathrm{f}$. sp. lactucae in a single seed assay. Because it has the 4-day incubation period, this test requires approximately 6 days to complete, compared with 10 days for the freezer blotter test or the direct plating method. Another advantage of the assay is that it does not rely on visual identification of $F$. oxysporum $\mathrm{f}$. sp. lactucae on lettuce seed, which is complicated by the frequent occurrence of morphologically similar species, especially in the Fusarium genera, that may also be present on lettuce seed. Thus, this PCRbased assay has the potential to be used for routine testing of lettuce seed lots for $F$. oxysporum f. sp. lactucae. Moreover, this type of test may have applicability for the detection of other fungal pathogens on seed of other crops once appropriate primer pairs are developed.

\section{ACKNOWLEDGMENTS}

The present work was supported, in part, by the College of Agriculture and Life Sciences, University of Arizona; the Arizona Iceberg Lettuce Research Council; and the Arizona Seed Trade Association.

\section{LITERATURE CITED}

1. Alves-Santos, F. M., Ramos, B., GarcíaSánchez, A. M., Elslava, P. A., and DíazMínguez, J. M. 2002. A DNA-based procedure for in planta detection of Fusarium oxysporum f. sp. phaseoli. J. Phytopathol. 92:237-244.

2. Baker, K. F. 1948. Fusarium wilt of garden stock (Matthiola incana). J. Phytopathol. 38:399-403.

3. Besri, M. 1978. Phases de la transmission de Fusarium oxysporum f. sp. lycopersici et de Verticillium dahliae par les semences de quelques variétés de tomate. Phytopathol. Z. 93:148-163.

4. Burgess, W. L., Summerell, B. A., Bullock, S., Gott, K. P., and Backhouse, D. 1994. Laboratory Manual for Fusarium Research, 3rd ed. University of Sydney and Royal Botanic Gardens, Sydney, Australia.

5. Chiocchetti, A., Sciaudone, L., Garibaldi, A., and Migheli, Q. 2001. PCR detection of Fusarium oxysporum $\mathrm{f}$. sp. basilica on basil. Plant Dis. 85:607-611.

6. De Boer, S. H., Ward, L. J., Li, X., and Chittaranjan, S. 1995. Attenuation of PCR inhibition in the presence of plant compounds by addition of BLOTTO. Nucleic Acids Res. 23:25672568.

7. Fujinaga, M., Ogiso, H., Shinohara, H., Tsushima, S., Nishimura, N., Togawa, M., Saito, H., and Nozue, M. 2005. Phylogenetic relationships between the lettuce root rot pathogen Fusarium oxysporum $\mathrm{f}$. sp. lactucae races 1, 2, and 3 based on the sequence of the intergenic spacer region of its ribosomal DNA. J. Gen. Plant Pathol. 71:402-407.
8. Fujinaga, M., Ogiso, H., Tsuchiya, N., and Saito H. 2001. Physiological specialization of Fusarium oxysporum f. sp. lactucae, a causal organism of Fusarium root rot of crisp head lettuce in Japan. J. Gen. Plant Pathol. 67:205206.

9. Fujinaga, M., Ogiso, H., Tushiya, H. S., Yamanaka, S., Nozue, M., and Kojima, M. 2003. Race 3, a new race of Fusarium oxysporum $\mathrm{f}$. sp. lactucae determined by a differential system with commercial cultivars. J. Gen. Plant Pathol. 69:23-28.

10. Garcia-Garza, J. A., Fravel, D. R., Nelson, J. A., Elias, K. S., Bailey, B.A., Gardini, A. E., and Darlington, C. 1999. Potential for dispersal of Fusarium oxysporum f. sp. erythroxyli by infested seed. Plant Dis. 83:451-455.

11. Garibaldi, A., Gilardi, G., and Guilino, M. L. 2002. First report of Fusarium oxysporum on lettuce in Europe. Plant Dis. 86:1052.

12. Garibaldi, A., Gilardi G., and Gullino, M-L 2004. Seed transmission of Fusarium ox ysporum f. sp. lactucae. Phytoparasitica 32:6165 .

13. Hirano, Y., and Arie, T. 2006. PCR-based differentiation of Fusarium oxysporum f. sp; lycopersici and radicis-lycopersici and races of F. oxysporum f. sp. lycopersici. J. Gen. Plant Pathol. 72:273-283.

14. Hu, X., Nazar, R. N., and Robb, J. 1999. Quantification of Verticillium biomass in wilt disease development. Physiol. Mol. Plant Pathol. 42:23-36.

15. Huang, J. H., and Lo, C. T. 1998. Wilt of lettuce caused by Fusarium oxysporum in Taiwan. Plant Pathol. Bull. 7:150-153.

16. Hubbard, J. C., and Gerik, J. S. 1993. A new wilt disease of lettuce incited by Fusarium oxysporum f. sp. lactucum forma specialis nov. Plant Dis. 77:7.

17. International Seed Testing Association. 1966. International rules for testing, 1966. Proc. Int. Seed Test. Assoc. 31:1-152.

18. Jobes, D. V., Hurley, D. L., and Thien, L. B. 1995. Plant DNA isolation: a method to efficiently remove polyphenolics, polysaccharides, and RNA. Taxon 44:379-386.

19. Kuniyasu, K., and Kishi, K. 1977. Seed transmission of Fusarium wilt of bottle gourd, $\mathrm{La}$ genaria siceraria Standl. used as rootstock of watermelon. II. The seed infection course from the infected stem of bottle gourd to the fruit and. Ann. Phytopathol. Soc. Jpn. 43:192-198.

20. Lee, S. B., and Taylor, J. W. 1990. Isolation of DNA from fungal mycelia and single spores. Pages 282-287 in: PCR Protocols. A Guide to Methods ad Applications. M. A. Innis, D. H. Gelfand, J. J. Sninsky, and T. J. White, eds. Academic Press, San Diego, CA.

21. Matheron, E. M. 2005. Effect of planting date, cultivar, and stage of plant development on incidence of Fusarium wilt of lettuce desert production fields. Plant Dis. 89:565-570.

22. Matheron, M. E., and Koike, S. T. 2003. First report of Fusarium wilt of lettuce caused by Fusarium oxysporum f. sp. lactucae in Arizona. Plant Dis. 87:1265.

23. Matuo, T., and Motohashi, S. 1967. On Fusarium oxysporum f. sp. lactucae n. f. causing root rot of lettuce. Trans. Mycol. Soc. Jpn. 32:13-15

24. Mbofung, C. Y. G., Soon Gyu, H., and Pryor, B. M. 2007. Phylogeny of Fusarium oxysporum f. sp. lactucae inferred from mitochondrial small subunit, elongation factor $1-\alpha$, and nuclear ribosomal intergenic spacer sequence data. J. Phytopathol. 97:87-98.

25. McCreight, J. D., Matheron, M. E., Tickes, B. R., and Platts, B. 2005. Fusarium wilt race 1 on lettuce. HortScience 40:529-531.

26. Millani, M. J., Etebarian, H. R., and Alizadeh, A. 1999. Occurrence of Fusarium wilt of lettuce in Shahre-Ray, Varamin and Karaj areas. Iran. J. Plant Pathol. 35:44-45. 
27. Murillo, I., Cavallarin, L., and San Segundo, B. 1998. The development of a rapid PCR assay for detection of Fusarium moniliforme. Eur. J. Plant Pathol. 104:301-311.

28. Neergaard, P. 1977. Seed Pathology, Volume I. Halsted Press, New York.

29. Ogiso, H., Fujinaga, M., Saito, H., Takehara, T., and Yamanaka, S. 2002. Physiological races and vegetative compatibility groups of Fusarium oxysporum f. sp. lactucae isolated from crisphead lettuce in Japan. J. Gen. Plant Pathol. 68:292-299.

30. Pasquali, M., Dematheis, F., Gilardi G., Gullino, M. L., and Garibaldi, A. 2005. Vegetative compatibility groups of Fusarium oxysporum f. sp. lactucae from lettuce. Plant Dis. 89:237-240.

31. Plyler, T. R., Simone, G. W., Fernandez, D., and Kistler, H. C. 1999. Rapid detection of the
Fusarium oxysporum lineage containing the Canary Island date palm wilt pathogen. J. Phytopathol. 89:407413.

32. Pryor, B. M., and Gilbertson, R. L. 2001. A PCR-based assay for detection of Alternaria radicina on carrot seed. Plant Dis. 85:18-23.

33. Rudolph, B. A., and Harrison, G. J. 1945. The invasion of the internal structure of cotton seed by certain Fusaria. J. Phytopathol. 35:542-548.

34. Shimazu, J., Yamauchi, N., and Hibi, T. 2005. Development of sequence tagged sites markers to identify races of Fusarium oxysporum f. sp. lactucae. J. Gen. Plant Pathol. 71:183-189.

35. Snyder, W. C. 1932. Seed dissemination in Fusarium wilt of pea. J. Phytopathol. 22:253257.

36. Talma, K., and Di Primo, P. 1999. Current status of vegetative compatibility groups in Fusarium oxysporum: (Suppl.) Phytopara- sitica 27:4

37. Taylor, J. 1993. A simple, sensitive, and rapid method for detecting seed contaminated with highly virulent Leptosphaeria maculans. Appl. Environ. Microbiol. 59:3681-3685.

38. Taylor, E., Bates, J., Kenyon, D., Maccaferri, M., and Thomas, J. 2001. Modern molecular methods for characterization and diagnosis of seed-borne fungal pathogens. J. Plant Pathol. 83:75-81

39. Ward, E., Foster, S., Fraaije, B. A., and McCartney, H. A. 2004. Plant pathogen diagnostics: immunological and nucleic acid-based approaches. Ann. Appl. Biol. 145:1-16.

40. Zhang, Z., Zhang, J., Wang, Y., and Zheng, X 2005. Molecular detection of Fusarium ox ysporum f. sp. niveum and Mycosphaerella melonis in infected plant tissues and soil. FEMS Microbiol. Lett. 249:39-47. 